By AGNES REAGAN

\title{
College Library Exhibits: A Bibliographical Approach
}

Miss Reagan, of the staff of the Wellesley College Library, deals here comprehensively with the literature which may be suggestive in the planning of exhibits in. college libraries.*

$I^{N}$ A STUDy of college library exhibits the 1 existing literature relevant to the subject serves as a starting point and provides a background essential to its further development. A selection of titles has been made from this literature on the basis of those which point to the variety of available materials dealing with exhibits and which, at the same time, suggest answers to questions confronting a college librarian engaged in planning an exhibit program. Such questions may involve the techniques and methods which contribute to the making of an effective and successful exhibit, sources of exhibitable materials and ideas, and the purpose and value of exhibits in the college library. A librarian with an understanding of the general techniques and fundamental principles of exhibit planning in its broadest interpretation and with a definite purpose to accomplish through exhibition may be able to find in the literature descriptions of specific exhibits from which ideas as to content and arrangement may be borrowed.

\footnotetext{
* Based on a thesis presented in partial fulfillment of requirements for the degree of Master of Arts in Library Science at the University of Illinois. Used with permission of the dean of the graduate school.
}

One of the most detailed and practical explanations of library exhibit technique and method is found in G. O. Ward's Publicity for Public Libraries. ${ }^{1}$ The author in a chapter on displays and exhibits covers all sides of the question, from qualities which tend to make an exhibit effective to a formula for mixing an adhesive recommended for attaching labels inside exhibit cases. Advantages and limitations of the exhibit are enumerated, various types of exhibits are described, and physical equipment, including racks, panels, labels, and cases, is discussed. Mr. Ward's chapter in its practical approach based upon a sound study of the psychology of exhibiting is invaluable to the college librarian who will adapt and modify it to fit the college library. This discussion may be supplemented by two articles drawing their content primarily from exhibit policy and practice as developed and tested in specific libraries: "The Technique of Library Exhibits" by Eunice Wead, ${ }^{2}$ written with special reference to the library of the University of Michigan, and "The Huntington Library's Special Exhibitions" by R. O. Schad. ${ }^{3}$ Mr. Schad mentions exhibitions assembled to parallel instructional work in

\footnotetext{
1 Ward, G. O. Publicity for Public Libraries. 2d ed. New York, H. W. Wilson Company, 1935. 2 Wead, Eunice. "The Technique of Library Ex hibits." Library Journal 47:499-501, June 1, 1922. 3 Schad, R. O. "The Huntington Library's Special Exhibitions." Library Journal 59:642-45, Sept. r, 1934.
} 
nearby colleges. Two articles recently appearing in German periodical literature ${ }^{4}$ may be added for additional information regarding the elements which combine to make a successful book exhibition. Wilson Library Bulletin ${ }^{5}$ has always shown an awareness of the potentialities of exhibiting as one aspect of library service. In complete articles, in short paragraphs in "The Crow's Nest," and in the current "Display for the Month" are descriptions of successful exhibits shown in school, public, and college libraries, as well as more general discussions of display arrangement, poster making, and bulletin board technique. ${ }^{6}$

The practical use of the techniques and methods of exhibition discussed in the above references comes in their application to the selection and arrangement of materials for the purpose of expressing or exhibiting ideas. In addition to an understanding of display technique and method, a library exhibitor will find a knowledge of a few of the more fruitful sources of exhibitable materials and ideas useful.

An article from the Enoch Pratt Free Library, ${ }^{7}$ indicating individuals and organizations in the community that may lend exhibit materials, suggests to the college librarian sources on or near the college

"Sattler, Paul. "Ausstellungen als bibliothekarische Aufgabe." Zentralblatt für Bibliothekswesen 54:498-5I I, Sept.-Oct., I937; Rumpf, Walter. "Die kleine Buchausstellung." Bücherei 7:269-74, September 1940. Summaries may be found in Library Literature.

Wilson Library Bulletin, 1914-date. New York. H. W. Wilson Company, I922-date. Formerly Wilson Bulletin for Librarians.

A useful bibliography of display techniques was distributed to librarians attending the recent regional institute in Chicago: "Display Techniques," compiled by Matilde Kelly (Mimeographed, Chicago, 1943). A second up-to-date bibliography containing a section on exhibits, posters, and displays is avail. able from the Public Relations Division of the American Library Association: "Library Publicity Literature," compiled to I94I by Kenneth R. Shaffer; revised to I943 by Public Relations Division, American Library Association (Mimeographed, Chicago, 1943 ).

${ }_{7}^{7}$ Smith, Gretta. "Making Friends for the Library through Exhibits." Library Journal 59:646-49, Sept. I, I 934 . campus, including faculty, students, and alumni. "Leads No. 7,"8 from the American Library Association, gives specific sources for rented and borrowed exhibits. Textbooks from the field of visual education, such as $A$ udio-Visual Aids to Instruction, ${ }^{9}$ contain sources of materials and equipment. "Visual Aids in the Realm of Chemistry," 10 with its listing of charts, exhibits, pictures, and publications useful in secondary school and college chemistry, is an example of the curricular lists prepared by the Visual Aids Service of New Jersey State Teachers College. Other fields similarly covered by this same service include biology, English language and literature, health, mathematics, and music. In addition to the selected titles mentioned here, library, educational, and popular periodicals, Wilson's Vertical File Service, "plus native imagination," light other sources of exhibit materials.

\section{Related Materials}

In an exhibit the idea illustrated by related materials is as important as the actual materials themselves. Therefore, in the literature of library exhibits sources of exhibitable ideas are as pertinent as sources of exhibitable materials. Often a list of exhibit subjects may serve as a beginning upon which one exhibit or a series of exhibits may be built. A wide variety of topics tried and proved exhibitable is found under the subject heading "Exhibits" in Library Literature. ${ }^{12}$ Typi-

8 American Library Association. Publicity Committee. "Visual Materials." ("Leads No. 7," revised.) Mimeographed, Chicago, 1939.

9 McKown, H. C., and Roberts, A. B. AudioVisual Aids to Instruction. New York, McGrawHill Book Company, Inc., I940.

10 New Jersey State Teachers College, Montclair. Visual Aids Service. "Visual Aids in the Realm of Chemistry." (Mimeographed, Montclair, I 940.)

11 American Library Association, op. cit. p. ii.

12 Library Literature, 1933-35- date. New York, H. W. Wilson Company, I936-date. 
cal annual reports of college librarians indicate briefly the name or theme of each exhibit shown during the period covered by the "report. In addition to college library bulletins, such as Colby Library Quarterly ${ }^{13}$ and Wesleyan University's About Books, ${ }^{14}$ bulletins of university and public libraries carry articles which can in some degree be translated for use in the college field. Although the average college library will not contain in any great measure the manuscripts and first editions which lend themselves so readily to exhibition in the larger university and public libraries, accounts of these exhibitions may be suggestive of exhibitable subjects and, less frequently, of ideas regarding techniques, practices, and materials. Descriptions of fifteenth century books published in the Boston Public Library's More Books ${ }^{15}$ are useful in the college library showing rare books. A number of topics from the list of exhibitions in the forty-year index to the Bulletin of the New York Public Library ${ }^{16}$ are susceptible to college exhibition. An article on Harvard University's tercentenary exhibitions $^{17}$ suggests techniques as well as subjects.

\section{Titles from Reading List}

Occasionally a library may be able to build an entire exhibit of titles selected from a reading list, such as one designed to accompany the New York Public Library's exhibition "Women in the Making

\footnotetext{
13 Colby College, Waterville, Me., Library. Colby Library Quarterly, 1943-date.

14 Wesleyan University, Middletown, Conn. Olin Memorial Library. About Books, r930-date.

15 Boston Public Library. More Books, $1926-$ date.

${ }_{16}$ New York Public Library. Bulletin... Index to Volumes $1 * 40,1897-1936$, compiled and edited by D. C. Haskell. New York, I 937.

17 Walton, C. E. "Tercentenary Exhibitions." Harvard Unniversity, Cambridge, Mass., Library. Harvard Library Notes $3: 187-94$, May i938.
}

of America," 18 or from the catalog of an exhibit, such as the catalog of the exhibition at Mount Holyoke to commemorate the one hundredth anniversary of the college. ${ }^{19}$ A cap and gown exhibit shown in the library of the University of Rochester is described in such detail as to be of real assistance to the college librarian interested in a commencement exhibit. ${ }^{20}$ The Goucher College Library's exhibit of "A Half-Century of 'Textbooks"21 and documents exhibits at Florida State College for $W_{o m e n}{ }^{22}$ are presented with sufficient fulness to make them patterns for librarians assembling collections of similar materials.

The number of instances in which the exhibit policies of individual college libraries have been described in approximate detail is relatively small. For the most part, ends toward which exhibits may be made to work must be discovered from general articles upon college library service or from accounts of single exhibits: art exhibits shown for their cultural effect, hobby exhibits to enlist the interest of students and faculty members, permanent exhibits to publicize rare items, displays of current books to stimulate reading, teaching exhibits to implement the work of the college faculty. Frequently, however, there is little indication of the purpose and value of these exhibits either within the total exhibit program of the library or within the educational program of the college.

18 "Women in the Making of America." New York Public Library. Bulletin 45:468.72, June 1941. 19 Mount Holyoke College, South Hadley, Mass. Williston Memorial Library. An Exhibition of One Hundred American First Editions Paralleling the Hindred American First Editions Paralleling the ${ }_{20}$ "The Crow's Nest." Wilson Bulletin for $L i$. brarians 10:600-02, May 1936.

${ }_{21}$ Schindler, M. E. "A Ḧalf-Century of Textbooks." Journal of Higher Education 10:210-13, April 1939.

22 Haynes, Frances, and Coykendall, Frances. "Documents Can Be News." Wilson Library Bulletin 1 7:544-45, March 1943. 
Library Exhibit Policies

Among the colleges with library exhibit policies clearly defined in library literature are Seton Hall College, Wellesley College, and Williams College. The exhibit program of Seton Hall College, outlined for a three-year period and planned to interest students in nonrequired reading, is discussed by Sister Melania Grace in Catholic Library $W$ orld. ${ }^{23}$ Parts of the exhibit programs of Wellesley and Williams bear directly upon courses in the curriculum. Public and teaching exhibitions in the Wellesley College Library are described in the annual report of the librarian for the year $194 \mathrm{I}-42 . .^{24}$ The custodian of the Chapin Library at Williams College has contributed two of the most significant and stimulating articles to be found in the literature of library exhibits. The first article, published in 1936, discusses the use of rare books "to convey an idea or abstraction." ${ }_{25}$ A second article, appearing five years later, treats the role of rare books in a college program and describes the kinds of exhibits shown in the Chapin Library. ${ }^{26}$ These articles, coupled with the reports prepared annually by the custodian, ${ }^{27}$ give the reader an excellent picture of exhibits as developed in one college library.

To conclude this brief review of titles selected from library literature because of their pertinence to the study of college library exhibits, reference may suitably be made to the chapter "Posters, Displays, Exhibits" in G. R. Lyle's College Library

23 Sister Melania Grace. "A Publicity Program for the College Library: A Three-Year Plan." Cath.

${ }_{24}$ Wibrary World 8:69.70, May 19.37.
olley College, Wellesley, Mass., Library.

"Report of the Librarian." I $941-42$. Mimeographed. ${ }_{25}^{2}$ Osborne, L. E. "Exhibitions." Library Journal 61:389, May I5, 1936.

20 Osborne, L. E. "Rare Books in a College Pro. gram." Library Journal 66:386-87, May I, I $94 \mathrm{I}$.

${ }^{27}$ Williams College, Williamstown, Mass. Chapin Library. Report, 1923-24-date.
Publicity. ${ }^{28}$ The topics covered aboveexhibit technique and method, sources of exhibitable materials and subjects, the purpose and value of exhibits-are summarized by $\mathrm{Mr}$. Lyle and pointed directly toward the college library.

It is clear that the literature of library exhibits includes writings of both a practical and a theoretical nature. The college librarian content with a surface knowledge of the subject will probably find sufficient information here, but in this literature at present are few penetrating studies. Writing to museum curators, one English authority on museum exhibition has said in discussing the main sources of "delight in display:"

Sources for inspiration in finding or designing these elements of delight should not be sought in the museum alone, since the danger in the practice of any art is to feed upon oneself. To avoid the dangers of such a stodgy diet and evade the evils of inbreeding it is a good thing to turn towards other horizons. ${ }^{2 \theta}$

Such a statement might appropriately be rephrased and directed toward library exhibitors. The librarian desiring a thorough understanding of exhibits must become a student of exhibit literature in related fields and of those writings which lie behind and help interpret modern exhibit practices. If the college librarian defines clearly the primary purpose which exhibits are to serve in his library and does not lose sight of that purpose in an examination of a larger body of literature, his exhibit program cannot fail to profit.

A library exhibitor, whether he considers himself propagandist or instructor or a combination of the two, can transfer a

\footnotetext{
2 Lyle, G. R. College Library Publicity. Boston, F. W. Faxon Company, 1935.

29 Thomas, Trevor. "Penny Plain, Twopence Coloured: The Aesthetics of Museum Display." Museums Journal 39:9, April 1939.
} 
number of well-developed and carefully tested techniques from fields making use of display either commercially or educationally. Both window display, designed primarily to sell, and museum exhibition, intended mainly to teach, have developed a literature which will lend itself to interpretation in terms of the library exhibit.

General handbooks on window display, similar to W. N. Taft's The Handbook of Window Display, ${ }^{30}$ discuss points to be considered in dressing a show window, applications of the principles of arrangement and color, and essentials of a good background. Retail Advertising and Sales Promotion by C. M. Edwards and W. H. Howard $^{31}$ offers a useful analysis of the principles basic to a good window display program. A more comprehensive treatment of successful utilization of light and color is contained in Matthew Luckiesh's Light and Color in Advertising and Merchandising. ${ }^{32}$

\section{Museum Exhibits}

Although the distinction between the functions of the college library and the museum of science and art is a marked one, the problem of exhibition is common to both, and the library exhibitor will find a familiarity with established practices and current developments in museum display to be useful. A brief summary by Elizabeth Eiselen of the techniques of museum exhibition ${ }^{33}$ affords a general introduction to the subject. Results of surveys at the New York and San Francisco World's Fairs of 1939, recently published by the

\footnotetext{
${ }^{80} \mathrm{Taft}, \mathrm{W}$. N. The Handbook of Window Display. New York, McGraw.Hill Book Company, Inc., 1926 ${ }^{81}$ Edwards, C. M., Jr., and Howard, W. H. Retail Advertising and Sales Promotion. New York, Prentice-Hall, Inc., 1936.

${ }_{32}$ Luckiesh, Matthew. Light and Color in Advertising and Merchandising. New York, D. Van Nos-

trand Company. Inc., 1923. "The Technique of Exhibits." Journal of Geography 39:320-22, 1940.
}

New York Museum of Science and Industry, ${ }^{34}$ show successful display techniques and trends in modern exhibition. L. V. Coleman in analyzing curatorial work in his Manual for Small Museums ${ }^{35}$ discusses purposes, arrangement, and installation of exhibits, as well as exhibition equipment. A librarian considering the purchase of a number of cases may wish to supplement Mr. Coleman's discussion with the chapter "Museum Fatigue" in B. I. Gilman's Museum Ideals of Purpose and Method. ${ }^{36}$

Serial publications dealing specifically with museum work carry material on labeling, arrangement, and display method. E. S. Robinson's The Behavior of the Museum Visitor, ${ }^{37}$ issued as one of the Publications of the American Association of Museums, contains suggestions for the librarian concerned with measuring the relative effectiveness of two exhibits. The study of any one of the more practical references on museum display might well be enlivened by the reading of an article in Museums Journal by Trevor Thomas of the Liverpool Free Public Museums. ${ }^{38}$ The article is among the best for pure inspiration and for an appreciation of exhibition arrangement as developed in the modern museum.

The values of graphic representation and the utilization of concrete objects in attracting attention and in clarification and interpretation of textual materials are in certain cases implied and in others discussed in some detail in the foregoing references. However, within recent years

34 New York Museum of Science and Industry. Exhibition Techniques. New York, 1940.

${ }^{35}$ Coleman, L. V. Manual for Small Museums. New York, G. P. Putnam's Sons, 1927.

${ }^{36}$ Gilman, B. I. Museum Ideals of Purpose and Method. Cambridge, Riverside Press, 1918.

37 Robinson, E.S. The Behavior of the Museum Visitor. American Association of Museums. Publications, New Series, 5, Washington, 1928.

${ }_{38}$ Thomas, op. cit., p. I-I 2. 
the field of visual education has made the greatest use of visual aids as supplementary instructional devices. Since emphasis has been laid upon the use of such aids within grade and high schools, the bulk of the literature has been prepared with the needs of elementary and secondary school teachers in mind. Even so, regardless of the intelligence and age level of the audience for which an exhibit is planned, an appreciation of the philosophy and psychology of visual aids is fundamental to the exhibitor, who will find it necessary in using the literature to remember that certain practices and techniques developed for an elementary schoolroom will frequently require some little modification to be applied successfully in a college library. For an understanding of the value and use of visual aids, standard textbooks, such as Audio-Visual Aids to Instruction ${ }^{39}$ and Visualizing the Curriculum, ${ }^{40}$ are helpful. Discussions of the "why" of visual materials and their place in the teaching program can be found here, as well as chapters devoted primarily to various types of graphic materials and objects with practical suggestions regarding their selection, care, and most effective use. Bibliographies point the way to similar materials bearing on specific curricular fields.

One of the most comprehensive treatments of the exhibit as an instrument of education lies within the field of social welfare. Although prepared for one particular group of exhibitors, The $A B C$ of Exhibit Planning by the Routzahns ${ }^{41}$ of-

\footnotetext{
${ }^{39}$ McKown, op. cit. S. B. Visualizing the Curriculum. New York, Cordon Company, I937.

${ }^{41}$ Routzahn, E. G., and Routzahn, M. S. The $A B C$ of Exhibit Planning. New York, Russell Sage Foundation, Igr8. A recent pamphlet on exhibits has been prepared by the National Publicity Council for Health and Welfare Services: Exhibits: How To Plan and Make Them. New York, National Publicity Council, I943.
}

fers general suggestions which will apply to any exhibit program. According to the editor's preface, it is concerned with the initial stages of exhibit preparation, when first decisions are being made regarding scope, purpose, and methods.

Back of all successful exhibit techniques and practices covered in library literature and in the literature of related fields lies an appreciation for the principles of aesthetics and an understanding of human nature and the means by which it can be most readily motivated and controlled. In this connection writings dealing with artistic design and applied psychology are relevant to a study of exhibitions.

In advertising, conformity to the more conventional aesthetic principles is encouraged since investigation has shown that people are in most cases sensitive to values basic to artistic design. ${ }^{42}$ Such conformity is equally desirable in exhibiting. An exhibit to be effective must be arranged in good taste, which calls for an intelligent application of elements usually associated with the fine and graphic arts. D. W. Ross in A Theory of Pure Design $^{43}$ presents the laws of harmony, balance, and rhythm as expressed through position, line and outline, tone, and color. Less detailed discussions of the fundamentals of design are found in Chapter III of E. A. Batchelder's Design in Theory and Practice P4 $^{4}$ and Chapter II of Essentials of Design by Charles De Garmo and L. L. Winslow. ${ }^{45}$ The latter work contains, also, an excellent section on the artistic significance of color.

\footnotetext{
42 Burtt, H. E. Psychology of Advertising. Boston, Houghton Mifflin Company, I 938, p. 296-97. ${ }^{43}$ Ross, D. W. A Theory of Pure Design. New York, Peter Smith, 1933.

\& Batchelder, E. A. Design in Theory and Practice. New York, Macmillan Company, rgro.

45 De Garmo, Charles, and Winslow, L. L. Essen tials of Design. New York, Macmillan Company, I924.
} 
Purpose of Exhibit

Generally an exhibit is prepared to be seen by a particular group of individuals and to influence that group in a prescribed manner. Therefore, an exhibit can hardly be judged completely effective if it fails to attract and hold the attention of those for whom it has been planned nor can it be considered wholly successful if the influence which it works upon its audience is contrary to the one expected. In this respect an acquaintance with the basic principles of applied psychology will prove of great assistance to an exhibitor. Since the field of advertising includes exhibiting and since psychology has been applied successfully within this field by modern business, the literature of psychology in advertising can contribute in no small measure to an understanding of the principles which underlie a good exhibit. Practical manuals of advertising, such as Introduction to Advertising by A. J. Brewster and H. H. Palmer ${ }^{46}$ and $A n$ Outline of $A d$ vertising by $\mathrm{G}$. B. Hotchkiss, ${ }^{47}$ contain chapters concerned with psychological principles which are applied in advertising and which can be applied with equal propriety in exhibiting. The discussions of certain points-appeals to basic interests and emotions, incentives to attention and interest, effective use of illustrations and color-clarify and summarize materials found in more comprehensive references on advertising psychology.

H. E. Burtt's Psychology of Advertisin $^{48}$ is representative of those books which treat the subject in greater detail and which at the same time are readable and

46 Brewster, A. J., and Palmer, H. H. Introduction to Advertising. $4^{\text {th }}$ ed. New York, McGrawHill Book Company, Inc., I94I.

${ }_{47}$ Hotchkiss, G. B. An Outline of Advertising. Rev. ed. New York, Macmillan Company, I 940. 48 Burt, op. cit. intelligible even to beginners in the field. Here the element of "appeal," often considered intangible, elusive, and the result of chance rather than actual planning, is placed within reach of the library exhibitor willing to read, adapt, and apply. The author covers types of appeals, their relative strength, and their adaptation to fit a particular audience. Chapters are devoted to mechanical devices for attracting attention, including size, intensity, motion, ${ }^{49}$ contrast, isolation, and position, and to techniques for holding attention, such as unity, balance, and the use of lines and closed forms. The importance of interest incentives-novelty, the comic, color, and pictures-which afford a linkage with some previous experience and arouse interest, is stressed. Any one or all of the psychological principles explained by Mr. Burtt may be utilized in exhibiting, with the extent of use depending always in the final analysis upon the purpose of the exhibit.

\section{Summary}

By way of summary it seems appropriate to venture a number of generalizations drawn from the literature discussed as pertinent to exhibits and to consider these generalizations in their application to the college library. What is an exhibit? What factors should be considered in its evaluation? What elements contribute to the making of a good exhibit?

One writer in an article on exhibit tech-

49 For the average library exhibit the use of light and motion may be highly impracticable, but there is no doubt as to their attention-attracting value, and, if a librarian is aware of their possibilities, one or the other may be utilized upon certain occasions without unreasonable expenditure or too elaborate preparation. The use which the library of the College of the City of New York has made of light and motion in exhibiting is given in Robert Whitford's tion in exhibiting is given in Robert Whitford's I $47 \cdot 48, \mathrm{Feb}$. I 5 , I 935 . 
nique defines an exhibit as "a means of imparting the same information over a period of time to many people." 50 A second author in a discussion of library publicity describes an exhibit as "an object or a collection of objects chosen and arranged so as to tell a story." 51 One factor discernible in the literature of library exhibits and substantiated by the results of a survey of college library exhibit practice is that no marked distinction has been made between an "exhibit" and a "display." To one librarian an exhibit worthy of the name may rival a lesser Century of Progress exhibition; to another it may be a miscellaneous collection of books assembled to the right of a circulation desk for the purpose of catching a prospective reader's eye and circulating immediately. As far as the individual library is concerned such a distinction is of minor importance. If a collection of materials shown publicly accomplishes the purpose for which it has been planned, the fact that these materials constitute an exhibit or a display is of little consequence. However, when an attempt is made to study collectively exhibits held within a number of libraries, some conclusion is needed as to the beginning of exhibit and the end of display. If the definitions proposed above are accepted, more than one so-called "exhibit" will automatically revert to the display group. If an exhibit is to tell the same story or teach the same lesson to a number of people over a period of time, every item in the exhibit which satisfies this definition will have a distinct role to play in its relation to other parts of the exhibit and in its contribution to the effectiveness and clarity of the whole. If the removal of any item detracts from the exhibit's effectiveness and leaves a gap in its story, its

so Eiselen, op. cit., p. 320.

51 Ward, op. cit., p. 201 . inclusion is justified. In view of the above definitions, it appears that the construction of an exhibit is not dependent upon the amount of material shown or the number of cases filled. It depends more reasonably upon another factor: to be effective, to teach its lesson, or to tell its story, the exhibit must be preserved as a whole during the period of exhibition. In this respect it differs from the display.

An exhibit without a purpose may find itself hard put to justify its existence, particularly within a library. Display for the sake of display may be effective, but it is scarcely to be considered as constituting an end in itself. A half-hearted effort on the part of any college library to carry on exhibits poorly planned and hurriedly executed may be open to criticism, for no exhibit at all is in most instances better than a poor exhibit. On the other hand, in view of the many demands upon staff members' time by more firmly established types of library service, there is little justification for an elaborate exhibit program unless it is soundly based and clearly defined. A clear definition of purpose, therefore, is fundamental to the planning of any exhibit. If that purpose can be accomplished more readily and practicably and with equal success by some means other than exhibiting, an exhibit should not be attempted.

As the purpose of an exhibit is fundamental to its planning it is also of first importance in its evaluation. The decisive test of the success of any exhibit comes in answer to the question: Was its purpose accomplished? An exhibit prepared to attract donations will be judged by the number of gifts resulting from it; a display intended to promote circulation of a particular group of books will be measured by statistics in the circulation 
record. Evidence of the success of an exhibit planned to teach a lesson or to tell a story is far less tangible and can hardly be measured in terms as concrete as gifts or statistics. If, however, in the planning, assembling, and arranging of the exhibit, thoughtful consideration is given the techniques of exhibition which are soundly based upon principles of applied psychology, the success of the exhibit will tend to be ensured.

The purpose of an exhibit once defined and justified will generally indicate the logical group toward which the exhibit should be directed. A college library exhibit prepared to attract donations will in all probability be directed toward prosperous alumni and influential Friends of the Library. An exhibit planned to enrich the teaching program of a certain faculty member will be aimed at students enrolled in his classes. Purpose and audience are inseparable in the preparation of an exhibit, and other factors to be considered will hinge largely upon these two. They govern the theme or central idea of the exhibit; they influence selection and arrangement of materials and the location of the exhibit itself; they determine the length of exhibition period and the type and amount of publicity the exhibit deserves. Purpose and audience serve as the framework around which an exhibit is built. How well the exhibit is built depends largely upon the judgment and skill with which the exhibitor selects and arranges his materials, relating them through appropriate written interpretations into an attractive whole which clearly expresses the theme of the exhibit.

The ideal college library exhibitor would seem to combine with the characteristics of librarian those of psychologist and artist with a proper balance among the three. He never allows his enthusiasm for drawing attention to the exhibit to overshadow its real purpose and divert attention elsewhere; he never permits his zeal for creating a masterpiece of artistry to make his primary purpose a secondary one; and he never lets his background as librarian blind him to the fact that, though books in themselves may be infinitely delightful to him, an exhibit of them can be made more attractive and alive to others if, in its planning and arrangement, a due regard is given the principles of applied psychology and artistic design.

\section{An Analysis of the Work of the Information Desk at the University of Illinois Library}

\section{(Continued from page 43)}

At the same time the attendant supplements printed rules with oral explanations applicable to the particular problem.

All things considered, it is evident that no printed handbook can be expected to take the place of an information service conveniently located and attended by a trained librarian who can not only explain general rules but also give specific help with the problem at hand. An information desk provides personal instruction in use of the library at the point where the student is most likely to encounter a need for such instruction. 